\title{
Indigenous fire management: a conceptual model from literature
}

\author{
William D. Nikolakis $^{1,2}$ and Emma Roberts ${ }^{2}$
}

\begin{abstract}
Culture influences how fire is perceived and managed in societies. An increasing risk of catastrophic wildfire has shifted political and academic attention on the use of Indigenous fire management (IFM) as an alternative to the common fire suppression paradigm. However, what is IFM? Here we conduct a conceptual framework analysis of scientific and scholarly literature to enhance our understanding of this complex global phenomenon. We present the five main concepts of IFM from literature and the relationships between them. This framework contributes to the development of a theory of IFM, examining the ontological, epistemological, and methodological issues within this evolving and dynamic phenomenon.
\end{abstract}

Key Words: conceptual analysis; fire ecology; fire management; Indigenous peoples

\section{INTRODUCTION}

Fire is perceived through the lens of culture, and is rooted in mythology and religion. In Ancient Greek mythology, the Titan Prometheus took fire from the Gods, and Indigenous cultures from the Pacific Northwest tell of fire being stolen by coyote, beaver, and dog, and then gifted to humans (Judson 1912). Western religions cast fire as being pagan, destructive, and even apocalyptic, shaping modern Western perspectives on fire (Wiebe 2008), and fire management (Pyne 2016). Despite the different narratives, fire is central to human development (Gowlett 2016, Pyne 2016), and has transformed our societies and landscapes (Boyd 1999, Laris 2002, Butz 2009, Wrangham 2009, Miller and Davidson-Hunt 2010).

Paleoecological and oral evidence shows Indigenous societies have used fire to manage landscapes regularly over millennia, and many groups still actively do this today (Kimmerer and Lake 2001, Archibald et al. 2012, Huffman 2013, Klimaszewski-Patterson et al. 2018). Many fire-dependent ecosystems are reliant on anthropogenic fire (Marsden-Smedley and Kirkpatrick 2000, Yibarbuk et al. 2001, Pellatt and Gedalof 2014), and fire is used to create food security, termed "fire-stick farming" in Australia (Jones 2012). Yet, a paradox exists, where the global land area burned has declined over the last two decades because of factors such as agricultural expansion and fire suppression (Andela et al. 2017), while the incidence of destructive fires is increasing because of factors like climate change and mismanagement (Flannigan et al. 2009, Jolly et al. 2015). The world is not seeing more fire, but is experiencing the wrong type of fire, in the wrong place, at the wrong time (Pyne 2016). Controlled burning to mitigate uncontrolled fires is critical in fire-dependent ecosystems. However, significant legal, political, and attitudinal barriers constrain this practice (Maguire and Albright 2005, North et al. 2015). Indigenous fire management (IFM) is increasingly touted as a way to bring fire back to landscapes (Russell-Smith et al. 2013, Mistry et al. 2016, Lake and Christianson 2019, Moura et al. 2019), but what is IFM?

Indigenous peoples across the world manage their lands with fire, guided by their knowledge, practices, lore, and customs (Yibarbuk et al. 2001, Huffman 2013, Zander et al. 2013, Lake et al. 2017, Rodriguez 2017, Moura et al. 2019). IFM is the proactive use of fire to achieve multiple and complex landscape-level objectives, such as cleaning the landscape, mitigating destructive wildfires, and reducing greenhouse gas emissions (Whitehead et al. 2008, Russell-Smith et al. 2015); ceremony (Fache and Moizo 2015); promoting biodiversity and food security (Boyd 1999, Lepofsky and Lertzman 2008); and generating sustainable livelihoods (Rasmussen et al. 2007, Fitzsimons et al. 2012, Russell-Smith et al. 2013, Mistry et al. 2016). We examine scholarly literature on IFM and its accompanying ontological (the nature of reality), epistemological (understanding reality), and methodological (ways for gaining knowledge about reality) complexities. Using a conceptual framework analysis approach, a grounded theory methodology (Jabareen 2009), we generate a conceptual model of IFM from scholarly literature, which illustrates its main concepts and their interrelationships as expressed in literature. We acknowledge that much of the scholarly literature is from a Western perspective, which is a significant limitation to this literature review. This paper offers a call to action to include Indigenous knowledge and voices on this important topic. The conceptual model developed from the literature can guide research and practice on this multidisciplinary phenomenon.

\section{CONTEXT}

Fire suppression, reflected in the figure of Smokey the Bear in North America, has dominated landscapes across the globe during the 20th century (Saveland 1998, Diver 2016). Fire is to be avoided and if unavoidable, extinguished to protect life and property (Pyne 1982). In a warmer world, uncontrolled wildfire remains a constant danger in fire prone areas, or "pyroscapes," with catastrophic megafires threatening ecosystems, infrastructure, and human populations (Hardesty et al. 2005, Flannigan et al 2009, Krawchuk et al. 2009, Moritz et al. 2012, Eloy et al. 2018). Indigenous peoples of pyroscapes often possess knowledge of fire and its use on these landscapes (Huffman 2013). Indigenous burning practices have notably shaped these pyroscapes over time (Bowman et al. 2011, Steen-Adams et al. 2019).

Historically, as European colonizers expanded across landscapes, IFM regimes were drastically altered (or quashed), which had consequences for the relationship between humans and fire, as well as negative impacts on landscape health (Pellatt and Gedalof 2014, Bird et al. 2016, Whitehair et al. 2018). IFM has declined since colonization, but it has continued in many areas and is being reactivated despite political barriers and conflicting worldviews 
with non-Indigenous stakeholders (Mistry et al. 2016). Landscapes have since been altered in fundamental ways by deforestation, agricultural development, grazing, invasive species, forest encroachment, urbanization, and climate change. In many cases, Indigenous fire knowledge and practice needs to be adapted to current and future conditions.

Recent record-breaking fires around the world have led to calls for decentralized and proactive fire management beyond fire suppression (Rasmussen et al. 2007, Charnley et al. 2015, North et al. 2015, Minor and Boyce 2018). A report by Abbott and Chapman (2018) in British Columbia, Canada called for the prioritization of proactive fire prevention, prescribed burning, and better fire management coordination with First Nations (Indigenous peoples). In the United States, a Forests and Rangelands (2014) government report recommended wildfire mitigation through risk reduction strategies and landscape restoration. An Australian CSIRO (2009) report proposed an adaptive fire management approach in order to accommodate climate change and biodiversity. There were also public calls for IFM in Australia after the 2019 fire season (see Fuller 2020).

The United Nations Sendai Framework for Disaster Risk Reduction 2015-2030, outlined that "Indigenous peoples, through their experience and traditional knowledge, provide an important contribution to the development and implementation of plans and mechanisms" for disaster risk reduction (United Nations Office for Disaster Risk Reduction 2015:23). The academy has also advocated for more Indigenous involvement in fire management (Rodríguez 2007, McGregor et al. 2010, Mason et al. 2012, Russell-Smith et al. 2015). Indigenous fire knowledge and practice can generate multiple social, economic, cultural, and environmental benefits (Northern Australia Environmental Resources Hub 2016) and IFM programs have been implemented in Australia, Canada, the United States, Brazil, and recently in Botswana. These programs involve collaborations between Indigenous and Western knowledge systems, and are embedded in, and shaped by the institutional context (Petty et al. 2015, Lake and Christianson 2019). Examining how IFM plays out within these collaborative processes and the institutional context is critical to understanding the development of IFM, and how it is applied as an alternative to fire suppression in specific areas.

\section{Institutional and policy context}

IFM was prohibited (and often displaced) over large areas (Ritchie 2009, Minor and Boyce 2018), particularly where Indigenous peoples were removed from their lands and resources, and forbidden from practicing their culture and language (Nikolakis 2019, Nikolakis and Nelson 2019, Nikolakis and Hotte 2020, Nikolakis et al. 2020). The emergence of IFM as a "legitimate" alternative to fire suppression involves a reactivation of Indigenous knowledge and enhanced participation in land governance (Whitehead et al. 2008, Huffman 2013, Sletto and Rodríguez 2013).

In countries like Canada, Australia, and the United States, subnational governments (states or provinces) typically have jurisdiction over fire management. On Indigenous lands, the federal or relevant Indigenous government is typically responsible for fire management. There can be a clash of values and goals for fire management, with subnational governments adopting a fire suppression approach, driven by Western knowledge and practices. Whereas Indigenous worldviews, knowledge, and practices call for a more place-based and holistic approach using fire as a tool (Berkes 1999, Kimmerer and Lake 2001, Norgaard 2014, Russell-Smith et al. 2017, Minor and Boyce 2018). In practice, it is common that fire management regimes neither match the ecological fire regime, nor do they draw from all available knowledge sources; this leads to negative ecological and social outcomes (Moura et al. 2019, Welch and Coimbra 2019).

Indigenous fire management goals are diverse, ranging from hazard reduction (Lewis et al. 2018), to maintaining biodiversity and cultural values, like protecting ceremonial areas (McGregor et al. 2010), to more localized cultural burning practices throughout the year (Kimmerer and Lake 2001, Bilbao et al. 2010, Steen-Adams et al. 2019) and enhancing livelihoods (Yibarbuk et al. 2001). For subnational governments, the goals are calibrated to land tenure, such as industrial forestry, rangeland, tourism, and conservation areas. In conservation areas, the fire-related goals are to maintain specific ecological values and to reduce wildfire risk, often achieved through prescribed burns (Fernandes and Botelho 2003). Efforts to integrate these different values and goals through comanagement approaches are well documented, and require parties to respect value differences, and to create rules about how these forms of knowledge and practice are integrated (Fitzsimons et al. 2012, Lake et al. 2017).

Barriers to implementing IFM include public perceptions of safety, air quality concerns, and other political complications (Marsden-Smedley and Kirkpatrick 2000). There are actor networks and advocacy coalitions advocating for IFM in policy processes, as a legitimate alternative to fire suppression (Diver 2016). Understanding the key concepts of IFM, and the interactions between these, is crucial to constructing a theory of IFM within the policy process.

\section{CONCEPTUAL BACKGROUND}

\section{Literature}

Early IFM literature took an etic approach to understanding precontact Indigenous fire regimes (Pyne 1982, Boyd 1999), studying communities from the outside. Recent literature increasingly takes an emic approach, as scholars build relationships with Indigenous communities, or communities produce their own literature, with the aim of exploring how Indigenous knowledge and practices interact with (or outside of) contemporary fire management. This often occurs in protected areas or on Indigenous lands. Most studies on contemporary IFM are at a local scale and measure cause and effect, governance, and the outcomes of IFM programs (particularly in Australia). Literature reviews have taken a social science lens (Christianson 2015) and a natural science lens focuses on prescribed burning (Fernandes and Bothelho 2003). Comprehensive studies have summarized the historical impact of humans on global fire regimes (Bowman et al. 2011), as well as the commonalities of Indigenous fire knowledge worldwide (Huffman 2013). However, there is a lack of global interdisciplinary synthesis of IFM. Although our conceptual model aims to advance understanding of this interdisciplinary topic, it is not necessarily representative of IFM as a whole, where other forms of knowledge are critical. A majority of the literature analyzed in this study, as well as the methods in which findings are presented (peer review, English language, etc.), have a Western lens. 
Table 1. Preliminary search of fire management topics.

\begin{tabular}{llc}
\hline \hline Topic & Search term & $\begin{array}{c}\text { Number of results from } \\
\text { Web of Science Core } \\
\text { Collection }\end{array}$ \\
\hline $\begin{array}{l}\text { Wildfire management } \\
\text { Prescribed burning }\end{array}$ & Wildfire AND management; fire AND management \\
$\begin{array}{l}\text { Carbon and wildfire management } \\
\text { Indigenous fire management }\end{array}$ & $\begin{array}{l}\text { Prescribed AND burning } \\
\text { Carbon AND wildfire AND management; carbon AND fire AND management } \\
\end{array}$ & $\begin{array}{l}\text { Indigenous AND fire AND management; aboriginal AND fire AND management; } \\
\text { aborigine AND fire AND management; "first nations" AND fire AND management }\end{array}$ \\
\hline
\end{tabular}

To fill this gap in global knowledge, a preliminary review of scholarly literature was first conducted using Boolean search terms in the topic field of the Web of Science core collection. Table 1 shows a relative dearth of IFM papers compared to overall fire management literature (around 1.66\%). This smaller literature, however, provides an opportunity for a deeper literature review and a multidisciplinary conceptual analysis of IFM.

\section{Conceptual drivers}

Ontology, epistemology, and methodology are crucial to understanding IFM. Ontology refers to the nature of reality, which is socially constructed through cultural symbols, ideas, belief systems, and narratives (Potter 1996). Reality can be reframed through shock events, or through actors reorienting how reality is perceived through learning. Epistemology refers to understanding "reality," determining what constitutes knowledge, distinguishing "truth" from simple opinion, and choosing what is worth knowing. Societies with diverse cultures, politics, and histories will have different ways of evaluating knowledge and determining truth (Henry and Pene 2001, Jasanoff 2004). Methodology is concerned with the methods, procedures, tools, and techniques for gaining knowledge. Methodology offers a justification and rationale for why certain procedures and tools are applied to investigate a given problem (Singh 2015). A methodology determines the approach for inquiry, and is guided by a researcher's ontological and epistemological position as they attempt to understand reality.

There are different knowledge systems for understanding the reality of fire and its management. Indigenous and Western science knowledge systems have differing (and sometimes common) epistemologies for how knowledge is uncovered or understood. There has been increasing focus on integrating Western and Indigenous knowledge to better understand and manage ecosystems and natural resources (Bohensky and Maru 2011). Western scientific paradigms create knowledge through critical reasoning, replicable methodologies, peer review, and written documentation, with ecological science increasingly focused on holistic systems thinking, resilience theory, and socialecological systems (Walker and Salt 2006, Bosch et al. 2007, Mason et al. 2012). Indigenous knowledge systems and science are often more experiential, localized, holistic, and are typically passed down orally through generations (Berkes 1999, Mason et al. 2012, Mistry and Berardi 2016). Both seek to understand phenomena by observing cause and effect, but the epistemological differences present challenges for collaborative approaches. Traditional knowledge holders may be hesitant to collaborate with the etic approach of Western science, uneven power dynamics, and skepticism about Indigenous knowledge (Moller et al. 2009). IFM in practice has mitigated these concerns by drawing from both Indigenous and Western scientific paradigms, and prioritizing Indigenous community participation in the application of knowledge (McGregor et al. 2010, Lake et al. 2017). This, in turn, allows methodologies to be created for finding solutions to fire management problems at broader scales.

There are various risks, perceived and real, for IFM as a methodology. Christensen (2003) and Stankey et al. (2003) document that mainstream fire management is generally risk averse. Decision makers avoid short-term risk in lieu of potentially long-term ecosystem benefits (Ryan et al. 2013). Fire management actors use mental shortcuts that introduce systemic bias and create a mismatch between objectives and practices (Maguire and Albright 2005). Often the precautionary principle is used, whereby the absence of fire is framed as a "safe alternative" to "risky" prescribed burning practices. Status quo bias is also prominent, where land managers feel less responsibility for the negative effects of "doing nothing," i.e., wildfire caused by climate change, than for the negative effects of deliberate interventions, i.e., damage from an escaped prescribed burn. Regret theory also plays a role, whereby land managers minimize potential losses rather than maximize the net value of a decision (Maguire and Albright 2005). These mental shortcuts inhibit innovative fire management policies and practices.

\section{IFM as a solution}

Locating IFM within broader environmental decision making brings insight to context. Figure 1 illustrates that environmental problems, their nature, and their recognition, are rooted in decision makers' ontologies. Once a problem is acknowledged, a risk-assessment is made and potential interventions are evaluated, drawing on existing knowledge and technical tools (Charnley et al. 2015). The portfolio of interventions for fire management are evaluated, be it fire suppression (status quo), prescribed burning, mechanical thinning, or a mixture of these. Where an intervention has previously been effective, it becomes the default option. Where the intervention has been ineffective, or the problem is unknown, then a space is created for interventions outside fire suppression (like IFM). If the solution is effective, we hypothesize this feedback will reshape existing ontologies to legitimate the innovation.

\section{METHODS}

To better understand emergent and multidisciplinary phenomena, Jabareen (2009) developed a "conceptual framework analysis" (CFA) approach, a grounded theory technique that builds a conceptual framework of "interlinked concepts that together provide a comprehensive understanding of a 
Table 2. Conceptual framework analysis: deconstructing and categorizing the concepts (adapted from Jabareen 2009).

\begin{tabular}{|c|c|c|c|}
\hline Concept & Description of concept & Inquiry character & $\begin{array}{l}\text { Selected sources of data (fields of } \\
\text { research) }\end{array}$ \\
\hline Distinct ontologies & Different culture and fire ontologies and knowledge. & Ontological & $\begin{array}{l}\text { Philosophy, anthropology, } \\
\text { ethnography }\end{array}$ \\
\hline Governance & $\begin{array}{l}\text { Power dynamics, institutions, tenure, Indigenous rights and } \\
\text { title, funding, political processes, colonialism, trust, } \\
\text { relationship-building, cross-cultural communication, } \\
\text { cogovernance, and stakeholder coordination. }\end{array}$ & Methodological & $\begin{array}{l}\text { Governance, law, history, } \\
\text { political science }\end{array}$ \\
\hline $\begin{array}{l}\text { Revitalizing Indigenous } \\
\text { knowledge }\end{array}$ & $\begin{array}{l}\text { Revitalization and mobilization of Indigenous fire knowledge } \\
\text { and practices, experiential/reflexive management, cultural } \\
\text { development, land management, intergenerational } \\
\text { transmission of oral knowledge. }\end{array}$ & Epistemological & $\begin{array}{l}\text { Anthropology, sociology, } \\
\text { ethnography, ethnobiology, fire } \\
\text { science, traditional ecological } \\
\text { knowledge }\end{array}$ \\
\hline Cobenefits & $\begin{array}{l}\text { Biodiversity, ecological outcomes, health and wellness, hazard } \\
\text { abatement, carbon credits, decreased greenhouse gas } \\
\text { emissions, livelihoods and cultural development. }\end{array}$ & Methodological & $\begin{array}{l}\text { Economics, ecology, community } \\
\text { development studies, population } \\
\text { health, fire science, climate } \\
\text { science }\end{array}$ \\
\hline Desired state & $\begin{array}{l}\text { Reversing degradation, human involvement in pyroscapes, } \\
\text { adaptation, heterogeneity/patchiness, "naturalness," resilience, } \\
\text { and ecosystem services (cultural values, water, carbon, etc.). }\end{array}$ & Epistemological & $\begin{array}{l}\text { Environmental psychology, } \\
\text { ecology, climate science, forest } \\
\text { policy, fire science }\end{array}$ \\
\hline
\end{tabular}

phenomenon" (Jabareen 2009:51). The goal of the analysis presented in this paper is to utilize the CFA approach to organize key concepts of IFM in ways that demonstrate interrelationships, as well as their ontological, epistemological, and methodological dimensions. The intention is to produce an illustrative framework of the multidisciplinary phenomenon in question, that contributes to its overall understanding. We employ Jabareen's eight-phase qualitative analysis to build a conceptual framework, which together compose a process of theorization. The theories in interdisciplinary literature form the data analyzed to build the conceptual framework, emphasizing a continuous interplay between data collection and analysis.

Fig. 1. Indigenous fire management (IFM) within environmental decision making. This dynamic framework shows environmental decision-making processes for a given environmental problem (in this case, wildfire). The dashed lines represent potential effects of ontologies on the decision-making process over time.

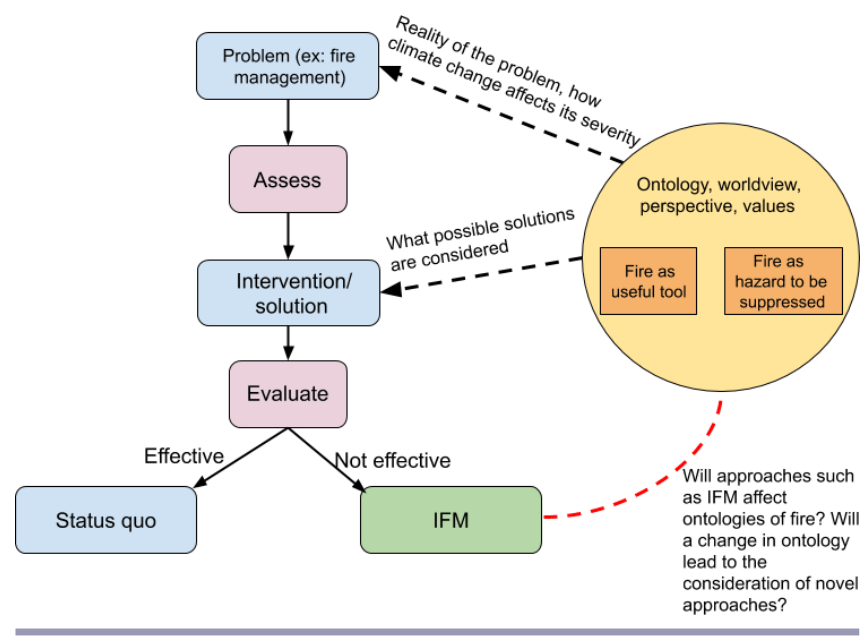

\section{Conceptual framework analysis}

The first phase involved a literature review of IFM, drawing on scholarly literature from ecology, fire science, community development, economics, and policy. This review identified 349 papers on IFM (see Table 1), and 72 were selected for deeper review, based on the following criteria: they were published after 2000 (to reflect contemporary rights and knowledge), and published in peer-reviewed journals. The second phase involved extensive reading and categorization of data, where literature was organized by discipline and relative importance within each discipline (by citations).

The third phase involved the identification of concepts within literature. The main findings and recommendations from each study were collated and grouped into overall themes, and from these groupings we documented common concepts. The fourth phase involved deconstructing each concept by identifying its main attributes and characteristics, and then organizing these concepts according to their ontological, epistemological, or methodological role. In the fifth phase, concepts were integrated, where they were reconsidered, combined, or dispensed with. The concepts were then synthesized into a theoretical framework (here presented as a contextual conceptual model) during the sixth phase.

The seventh phase involved validating the conceptual model to ensure it represents a reasonable theory for IFM from literature. In the eighth and final phase, the conceptual model was shared with academics and practitioners, and their feedback was incorporated where appropriate. Fifteen academics and fire practitioners were interviewed, including four academics from the U.S. (one Indigenous academic), four from Australia (one Indigenous practitioner), five from Canada (one Indigenous academic and practitioner), and two academics with work focused on Brazil and southern Africa.

\section{RESULTS}

A conceptual analysis identified five key concepts in the 72 articles. (1) Distinct ontologies: the ontology of fire is socially constructed and perceived differently by Western and Indigenous 
worldviews; (2) Governance: IFM often involves collaboration between Indigenous and Western knowledge systems, and occurs within a contested institutional context. (3) Revitalizing Indigenous knowledge: Indigenous knowledge and practices are rooted in an experiential epistemology where the landscape drives decision making. (4) Cobenefits: IFM can generate a range of ecological, social, economic, and cultural benefits. (5) Desired state: IFM can achieve a desired ecosystem state of resilience (Table 2).

\section{Concept \#1: distinct ontologies: fire ontologies are distinct in Western and Indigenous worldviews}

Relationally distinct fire ontologies exist: fire is either "good" or "bad," a "tool" or "hazard," "destructive" or "generative," and these views interact within existing institutional frameworks to shape the dominant epistemologies and methodologies for fire management.

Western fire ontologies have evolved over time. Heraclitus, of ancient Greece, believed all things were manifestations of fire (Wheelwright 1974), and later Aristotle classified fire as one of four elemental substances (Gomes 2018). In the 17th century, phlogiston theory reasoned all combustible materials contained the element "phlogiston," released into the air when something burned (Partington and McKie 1937). This theory was gradually superseded by our current scientific knowledge that fire is the combustion of fuels through the process of an exothermic reduction-oxidation reaction (for summary see Kondratiev 2018). As Western fire knowledge has evolved, so too has people's relationship with fire. Fire was a central aspect of domestic and daily routine, but following the Enlightenment and advances in technology, fire became less integrated into people's lives (Pyne 2016). Modernity has seen fire replaced by electricity for some, and the condemnation of fire by agronomists and foresters has reduced its use in land management and affirmed perceptions of fire as a destructive force to be suppressed (Pyne 2016).

In contrast, for many Indigenous peoples, the use of fire is based on a reciprocal relationship between the individual and the universe (Eriksen and Hankins 2014). Many Indigenous worldviews believe the Earth is a generative, living being, and that humans and all living beings are interconnected (Kidwell et al. 2002). As oral knowledge is important to Indigenous societies (Berkes 1999), fire knowledge, of when and how to use fire on the landscape, is often found in people's stories. These stories set out various "laws of the land" (Eriksen and Hankins 2014), for the responsibility of fire as a management tool and often incorporate the intrinsic value of nature, the potential for the landscape to be alive or sentient, and the spiritual dimensions of the land (Fernández-Llamazares and Cabeza 2018, Nikolakis et al. 2020). Fire is viewed by many Indigenous societies as a source of renewal, and burning cleans the landscape (Yibarbuk et al. 2001).

A clash of ontologies plays out in fire management in important ways. Colonizers brought European forest and fire management to areas they colonized and settled, despite many landscapes being fire-prone and fire-adapted (Pyne 2016). Colonization and fire suppression had drastic impacts on Indigenous people's ability to exercise their responsibilities to the land. It also changed these landscapes in important ways, as forests encroached on grasslands and fuel loads built up, enhancing the risk of devastating wildfire (Kimmerer and Lake 2001, Moura et al. 2019). IFM can not only mitigate risks, but can also contribute to the decolonization of fire management.

A significant ontological barrier to IFM is the idea of "traditional," where Western thinking frames traditional practices as those predating contact, and suggesting these are static (Pierotti 2018). Government agencies can simply reject IFM as an artefact with no place in modern landscapes (Mathews 2005). However, Indigenous cultures, worldviews, and knowledge systems are dynamic and adaptive, and can be applied to diverse settings and contexts (Berkes et al. 2000, Eriksen and Hankins 2014, Pierotti 2018). These distinct fire ontologies explain the divide in epistemologies and methodologies for fire management in colonized landscapes; the questions remain whether IFM can and should drive a convergence in ontologies.

\section{Concept \#2: governance: IFM is a collaboration influenced by political and power dynamics}

IFM takes place in a complex governance environment. IFM programs are often collaborative and draw from multiple bodies of knowledge and normative views of what should (and should not) be done to the landscape (see Shaffer 2010, Russell-Smith et al. 2013, Sletto and Rodríguez 2013, Lake et al. 2017, Eloy et al. 2018). Learnings across Indigenous and Western knowledge systems can foster new fire knowledge and goals, one prominent example being a community savanna-burning methodology in northern Australia (Whitehead et al. 2008, Russell-Smith et al. 2013). However, in practice, the broader institutional framework may entrench uneven power dynamics that influence knowledge production (Ballet et al. 2007, Hunt 2014). Mainstream actors and agencies may remain ignorant to the potential of IFM (Mathews 2005) and Indigenous peoples may determine it unacceptable to integrate their fire knowledge with, or having this validated by, Western science. As Miller et al. (2010:2298) argued, "Indigenous knowledge is inextricably linked to the rights of indigenous people to make choices, to preserve and recreate knowledge through continuing engagement and practice on the land."

Tenure systems, land management bureaucracy, and vested economic interests impede Indigenous people's access to environmental governance and climate adaptation strategies (Nikolakis and Nelson 2015, Nikolakis et al. 2016a, $b$, Nikolakis 2020). On top of this, strict antifire laws often prohibit Indigenous communities from burning, which puts IFM at risk (Kull 2002, Miller et al. 2010, Minor and Boyce 2018). International commitments made by states can either impede or complement IFM, further contributing to complexity in the governance environment. For example, commitments to reduce greenhouse gas emissions in the Kyoto Protocol enabled savanna burning as an accountable activity, allowing IFM to be integrated into carbon markets in Australia (see Russell-Smith et al. 2013), while also drawing criticism for how such market integration can institutionalize Indigenous knowledge (see Mistry and Berardi 2016). Comanagement involving Indigenous peoples and the state is one way to bridge epistemologies and methodologies for land governance, particularly where this respects the authority and sovereignty of the groups involved (see Diver 2016, Denham 2017, Latta 2018, Nikolakis and Hotte 2020). The reorientation of authority through comanagement, and more broadly selfgovernance, may facilitate IFM at a larger scale. 
A lack of funding and institutional support also impede IFM (Rasmussen et al. 2007, Fache and Moizo 2015). IFM is embedded in a complex governance environment, at various scales. As Mistry et al. (2019) document, IFM is an exercise in intercultural governance that requires carefully designed structures. Practitioners and academics emphasized that getting the governance right is dynamic and complex, but crucial for advancing IFM.

\section{Concept \#3: revitalizing Indigenous knowledge: Indigenous knowledge and practices are experiential and place-based}

Indigenous peoples continue their fire management practices in many places (Kimmerer and Lake 2001, Fulé et al. 2011, Pivello 2011, Russell-Smith et al. 2013, Sletto and Rodríguez 2013). Sometimes there is an integration of Indigenous and Western knowledge systems in IFM programs (McGregor et al. 2010, Mason et al. 2012, Lake et al. 2017, Lake and Christianson 2019). Where knowledge and practice have been discontinued, efforts to promote the revival of these practices are an urgent priority, and involve sharing knowledge across generations (McGregor et al. 2010, Huffman 2013, Mistry et al. 2016, Lewis et al. 2018, Nikolakis et al. 2020). Community goals for an IFM program in British Columbia, Canada included strengthening cultural connection and well-being, restoring the health of the land, and respecting traditional laws (Nikolakis et al. 2020).

Fire knowledge is epistemologically rooted in a connection to place (Robinson et al. 2016). Fire management can be a spiritual ceremony, grounded in local stories or legends (Davidson-Hunt and Berkes 2003, Miller et al. 2010, Christianson et al. 2014, Norgaard 2014). IFM emphasizes a reciprocal relationship with the land, and a strong nexus between individual and landscape health (Eriksen and Hankins 2014, Gratani et al. 2016). Under Indigenous epistemologies, the land often guides human action, while Western approaches are typically guided by politics, science, and economic incentives.

Drawing from Indigenous knowledge, IFM has been shown to be an effective place-based strategy to address wildfire and produce additional cobenefits (see Laris 2002, Whitehead et al. 2008, Russell-Smith et al. 2013) and has important self-governance implications (Diver 2016). It is of critical importance that where Indigenous and Western knowledge are brought together, it is in ways that ensure respect, equity, agency, and decision-making power for all parties involved.

\section{Concept \#4: cobenefits: IFM generates multiple ecological, social, economic, and cultural benefits}

In addition to reduced fire risk, literature demonstrates diverse market (income) and nonmarket (ecological, social, and cultural) outcomes from IFM (see for example Laris 2002, Bilbao et al. 2010, Hankins 2013, Bird et al. 2018), often termed cobenefits. IFM has generated significant greenhouse gas reductions by mitigating late dry season fires. The West Arnhem Land Fire Abatement (WALFA) project reduced carbon emissions from wildfire by $37.7 \%$ over seven years, relative to a preproject 10 -year emissions baseline (Russell-Smith et al. 2013). The WALFA project also generates livelihood outcomes through carbon credit sales (Whitehead et al. 2008). Tribal nations in the United States are interested in generating livelihood opportunities from IFM (Rasmussen et al. 2007) and tribes in Northern California are implementing IFM programs (Diver 2016). IFM can also deliver "conservation-based development" (Rasmussen et al. 2007).
Individual participation of Indigenous peoples in environmental management (including fire management) has produced positive health outcomes, derived from enhanced physical activity, reduced psychological distress, and increased connection to the land (Burgess et al. 2005). Campbell et al. (2011:83) concluded these programs deliver "significant and substantial savings in primary health care expenditure for the management of chronic disease." IFM programs also deliver individual emotional and spiritual health benefits (Miller et al. 2010, Norgaard 2014).

IFM programs enhance intergenerational knowledge and culture transfer, which is coupled with healthy and intact ecosystems (Fernández-Llamazares and Cabeza 2018). In Central Brazil, ceremonial practices and mentorship are combined to pass on fire knowledge (Welch and Coimbra 2019) and in British Columbia, educational programs and mentorship support IFM practices (Lewis et al. 2018).

"Pyrodiversity" describes the interactions between anthropogenic fire regimes, biodiversity, and ecosystem effects (Martin and Sapsis 1992, Bowman et al. 2016). In many savanna ecosystems, mosaic landscapes created through prescribed burning improve biodiversity (Laris 2002, Bilbao et al. 2010). Landscape mosaics with many small fires result in more long-unburnt patches (Trauernicht et al. 2015), which are important habitat for bird, reptile, and mammal species (Kelly et al. 2012, Taylor et al. 2012, Nimmo et al. 2013). However, Parr and Andersen (2006) argued the theory that "pyrodiversity begets biodiversity" has not received sufficient critical analysis, and that fire management should focus more on the specific levels of burning required for biodiversity goals, as well as operational guidelines for attaining them.

\section{Concept \#5: desired state of ecosystem: IFM can achieve a resilient ecosystem}

Determining what is a healthy ecosystem is socially constructed, and rooted in worldviews, values, and experiences (Papworth et al. 2009). Fire suppression in fire-prone regions has created a perception of safety, but has not achieved a desired healthy ecosystem state, and has paradoxically increased fire risk (Ingalsbee 2017). Understanding cultural fire regimes can help restore fire-prone ecosystems and their services (Steen-Adams et al. 2019). The desired state of an ecosystem is evolving and subject to shifting baselines, where people's perception of a healthy ecosystem changes from one generation to the next, or even within one's own lifetime, as their outlook changes (Papworth et al. 2009). This presents a risk as landscape knowledge is passed down to younger generations through a lens where negative ecological changes may go unnoticed and unaddressed. IFM has the potential to address this lapse in ecological memory by encouraging intergenerational knowledge transfer on what is a healthy or resilient ecosystem (Maffi and Woodley 2010).

The desire to achieve an ecosystem that is "natural" has epistemological flaws. The idea of "pristine nature" is a colonial idea that disregards Indigenous land management in markedly transforming the landscape (Denevan 1992, Gratani et al. 2016). The concept of nature, land use, and Indigenous land justice are bound up in the politics of territorialization, which shapes norms and rules for legitimating land access and use (Sletto 2016, Welch and Coimbra 2019). Further, climate change shapes what people see as the baseline of ecosystems, and hinders attempts to restore these to any baseline (Harris et al. 2006). Increasingly, there is a 
focus on integrating Indigenous knowledge and science with mainstream science concepts of systems thinking, resilience, and adaptive capacity in fire science, ecology, climate science, and many other relevant disciplines (Walker and Salt 2006, Bosch et al. 2007).

The need for adaptive strategies in fire management is critical (North et al. 2015, Mistry et al. 2016). IFM must be specific to the ecological characteristics of the landscapes to which it is applied, and this varies across biomes, regions, and ecosystems (see Kull 2002, Shaffer 2010, Russell-Smith et al. 2013, Lewis et al. 2018, Moura et al. 2019, Welch and Coimbra 2019, Nikolakis et al. 2020). Contemporary IFM must also consider critical infrastructure, land tenure, public risk perception, and air quality, which are crucial when managing populated landscapes. There are multitudes of competing objectives, goals, and narratives that influence IFM and its objectives.

\section{Conceptual model}

Figure 2 presents a conceptual model of the five key concepts of IFM from literature: (A) Multiple fire ontologies; (B) Governance; (C) Indigenous knowledge and practices; (D) Cobenefits; and (E) Desired ecosystem state. The interrelationships between these concepts are mapped out.

Fig. 2. Conceptual model. IK, Indigenous knowledge; WK, Western knowledge.

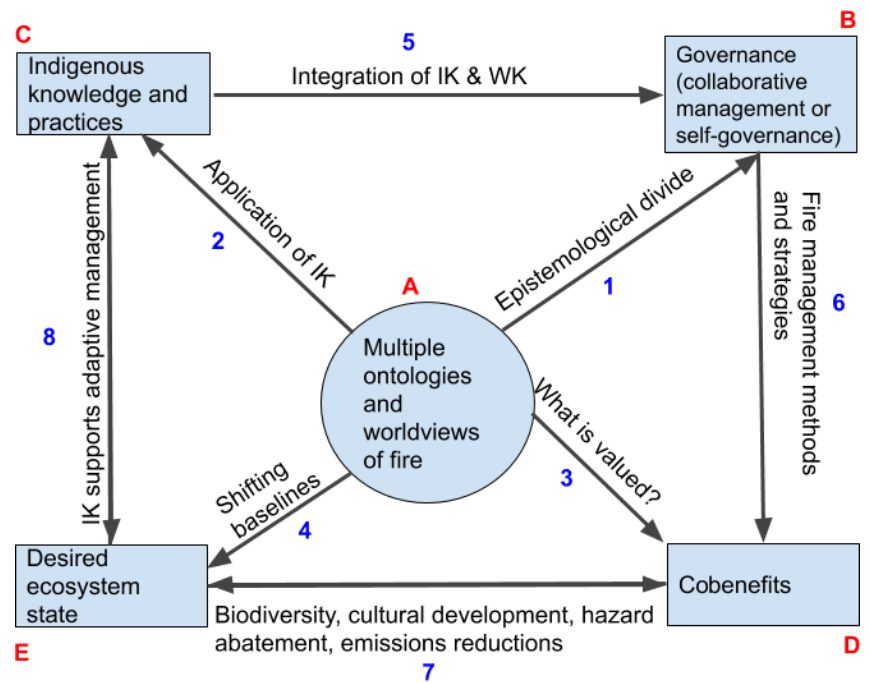

The conceptual model identifies (A) multiple fire ontologies, with different ways of knowing and thinking about fire. At (1), the model shows these ontological differences create an epistemological divide bridged by collaborative governance, which influences, and is influenced by, the institutional context (B). At (2), the application of IFM brings this into a broader fire management regime (C). At (3), ontological differences affect the cobenefits people value and manage for (D), with the tendency in Western perspectives to favor market benefits. Ontology also influences our ideas of how a desired ecosystem should appear and function (E). At (4), these ideas will change as our baseline of what a healthy landscape looks like evolves. At (5), integrating Indigenous and Western knowledge systems through collaborative processes can transform fire governance, the methods used, and benefits produced, at (6). At (7), the cobenefits managed for will influence the desired state of an ecosystem, for instance, managing for timber or carbon will have different implications for the ecosystem than managing for biodiversity or cultural values. Balancing these different goals and values requires participatory and adaptive forms of management, and Indigenous knowledge and practices can support this. At (8), the link between desired ecosystem state and Indigenous knowledge points both ways, as Indigenous knowledge is often experiential and involves a continuous interplay between applying strategies and reading the landscape.

\section{DISCUSSION AND CONCLUSIONS}

IFM is a practice and tool that can bridge distinct epistemologies of fire (Mason et al. 2012, Lake and Christianson 2019). However, IFM is distinct and exists on its own terms, outside of Western fire management frameworks. The conceptual model in Figure 2 presents five key IFM concepts from scholarly literature: fire ontologies, governance, Indigenous knowledge, cobenefits, and desired ecosystem state. The relationships between these are mapped out, illustrating the interdependencies between IFM concepts, as well as their accompanying ontological, epistemological, and methodological roles. These concepts play out to influence if and how IFM is used as a fire management strategy. This model aims to deepen understanding of the key elements of IFM represented in the literature, noting that most of this literature was developed by non-Indigenous academics. More effort to include and amplify Indigenous perspectives and worldviews on IFM is critical.

There are important temporal and spatial dimensions to IFM. The intervention depends on ecosystem type and season, and this creates challenges for knowledge sharing. Indigenous knowledge and practices are typically place-based and relevant to a specific fire regime and ecological context. For example, insights from north Australia's savannas are not readily transferable to Canada's boreal forest. That being said, the main concepts illustrated in the conceptual model (Fig. 2) were found to be representative of global IFM literature. The conceptual model captures important commonalities to implementing IFM.

As societies and communities learn to coexist with fire and expand thinking beyond Western ontologies and perspectives, there are important issues to consider. If IFM is pursued through marketbased mechanisms (like carbon credits), will this institutionalize and constrain the dynamism and experiential nature of Indigenous fire knowledge? Reciprocal relationships, and the connection between physical and spiritual worlds, are not easily integrated into Western scientific approaches (if integration is a management goal). New forms of governance will be important, and while adaptive comanagement is one way for bridging epistemologies and building trust, there remains questions about the ownership of Indigenous knowledge. One fire academic observed, "academics come and take the stories [of cultural fire] and it gets put out into the academic world, and that knowledge is taken away from the community." Putting safeguards in place to preserve Indigenous ownership of knowledge is crucial.

Institutions and power dynamics will shape the evolution of IFM. An Indigenous fire practitioner stated, "for Indigenous communities there is both a cultural and an ecological risk to not 
burning" [emphasis added]. They elaborated that "[ $t$ ]his results in risks for Indigenous communities performing their culture. Should they risk arrest to perform cultural fire ceremonies? Or should they risk a cultural loss by not performing them?" These laws, norms, and power dynamics may shift over time as IFM is implemented and legitimated by the dominant regime. There remain important questions as to whether IFM will expand beyond Indigenous land tenures, into contested areas as crises accelerate the acceptance of other fire solutions (see Fig. 1). As a fire academic reflected, "IFM is being considered as a solution because megafires are occurring, and this leads to a paradigm shift in fire management." It could be that as the benefits of IFM are demonstrated, this could facilitate a paradigm shift away from fire suppression, to more proactive and community-driven approaches. Further research is needed to better understand whether there exists a transformation toward IFM because fire suppression is demonstrably ineffective, or whether there is a broader shift in ontologies and epistemologies recognizing the importance of Indigenous knowledge for sustainable development in a changing climate.

Responses to this article can be read online at: http://www.ecologyandsociety.org/issues/responses. php/11945

\section{Acknowledgments:}

We would like to thank the interviewees and reviewers who took the time to provide insight to this paper.

\section{Data Availability:}

The datalcode that support the findings of this study are available in the literature review and Appendix 1. These datalcode were derived from a bibliometric analysis commenced 6 March 2019 from resources available in the public domain.

\section{LITERATURE CITED}

Abbott, G., and M. Chapman. 2018. Addressing the new normal: 21 st century disaster management in British Columbia A report for government and British Columbians. British Columbia Government, Victoria, British Columbia, Canada.

Andela, N., D. C. Morton, L. Giglio, Y. Chen, G. R. van der Werf, P. S. Kasibhatla, R. S. DeFries, G. J. Collatz, S. Hantson, S. Kloster, D. Bachelet, M. Forrest, G. Lasslop, F. Li, S. Mangeon, J. R. Melton, C. Yue, and J. T. Randerson. 2017. A human-driven decline in global burned area. Science 356:1356-1362. https://doi. org/10.1126/science.aal4108

Archibald, S., A. C. Staver, and S. A. Levin. 2012. Evolution of human-driven fire regimes in Africa. Proceedings of the National Academy of Sciences 109(3):847-852. https://doi.org/10.1073/ pnas. 1118648109

Ballet, J., N. Sirven, and M. Requiers-Desjardins. 2007. Social capital and natural resource management: a critical perspective. Journal of Environment \& Development 16(4):355-374. https://doi. org/10.1177/1070496507310740
Berkes, F. 1999. Sacred ecology: traditional ecological knowledge and resource management. Taylor and Francis, Philadelphia, Pennsylvania, USA.

Berkes, F., J. Colding, and C. Folk. 2000. Rediscovery of traditional ecological knowledge as adaptive management. Ecological Applications 10:1251-1262. https://doi.org/10.1890/1051-0761 (2000)010[1251:ROTEKA]2.0.CO;2

Bilbao, B. A., A. V. Leal, and C. L. Méndez. 2010. Indigenous use of fire and forest loss in Canaima National Park, Venezuela. Assessment of and tools for alternative strategies of fire management in Pemón Indigenous lands. Human Ecology 38 (5):663-673. https://doi.org/10.1007/s10745-010-9344-0

Bird, D. W., R. B. Bird, B. F. Codding, and N. Taylor. 2016. A landscape architecture of fire: cultural emergence and ecological pyrodiversity in Australia's Western Desert. Current Anthropology 57(13):S65-S79. https://doi.org/10.1086/685763

Bird, R. B., D. W. Bird, L. E. Fernandez, N. Taylor, W. Taylor, and D. Nimmo. 2018. Aboriginal burning promotes fine-scale pyrodiversity and native predators in Australia's Western Desert. Biological Conservation 219:110-118. https://doi.org/10.1016/j. biocon.2018.01.008

Bohensky, E. L., and Y. Maru. 2011. Indigenous knowledge, science, and resilience: What have we learned from a decade of international literature on "integration"? Ecology and Society 16 (4):6. https://doi.org/10.5751/ES-04342-160406

Bosch, O. J. H., C. A. King, J. L. Herbohn, I. W. Russell, and C. S. Smith. 2007. Getting the big picture in natural resource management-systems thinking as 'method' for scientists, policy makers and other stakeholders. Systems Research and Behavioral Science 24(2):217-232. https://doi.org/10.1002/sres.818

Bowman, D. M. J. S., J. Balch, P. Artaxo, W. J. Bond, M. A. Cochrane, C. M. D'Antonio, R. DeFries, F. H. Johnston, J. E. Keeley, M. A. Krawchuk, et al. 2011. The human dimension of fire regimes on Earth. Journal of Biogeography 38(12):2223-2236. https://doi.org/10.1111/j.1365-2699.2011.02595.x

Bowman, D. M. J. S., G. L. W. Perry, S. I. Higgins, C. N. Johnson, S. D. Fuhlendorf, and B. P. Murphy. 2016. Pyrodiversity is the coupling of biodiversity and fire regimes in food webs. Philosophical Transactions of the Royal Society B: Biological Sciences 371(1696). https://doi.org/10.1098/rstb.2015.0169

Boyd, R. 1999. Indians, fire and the land. Oregon State University Press, Corvallis, Oregon, USA.

Burgess, C. P., F. H. Johnston, D. M. J. S. Bowman, and P. J. Whitehead. 2005. Healthy country: healthy people? Exploring the health benefits of Indigenous natural resource management. Australian and New Zealand Journal of Public Health 29 (2):117-122. https://doi.org/10.1111/j.1467-842X.2005.tb00060. $\underline{\mathrm{X}}$

Butz, R. J. 2009. Traditional fire management: historical fire regimes and land use change in pastoral East Africa. International Journal of Wildland Fire 18(4):442-450. https://doi.org/10.1071/ WF07067

Campbell, D., C. P. Burgess, S. T. Garnett, and J. Wakerman. 2011. Potential primary health care savings for chronic disease 
care associated with Australian Aboriginal involvement in land management. Health Policy 99(1):83-89. https://doi.org/10.1016/ j.healthpol.2010.07.009

Charnley, S., M. R. Poe, A. A. Ager, T. A. Spies, E. K. Platt, and K. A. Olsen. 2015. A burning problem: social dynamics of disaster risk reduction through wildfire mitigation. Human Organization 74(4):329-340. https://doi.org/10.17730/0018-7259-74.4.329

Christensen, J. 2003. Auditing conservation in an age of accountability. Conservation in Practice 4(3):12-19.

Christianson, A. 2015. Social science research on Indigenous wildfire management in the 21st century and future research needs. International Journal of Wildland Fire 24:190-200. https:// doi.org/10.1071/WF13048

Christianson, A., T. K. McGee, and L. L'Hirondelle. 2014. The influence of culture on wildfire mitigation at Peavine Métis Settlement, Alberta, Canada. Society \& Natural Resources 27:931-947. https://doi.org/10.1080/08941920.2014.905886

Commonwealth Scientific and Industrial Research Organisation (CSIRO). 2009. Bushfires in Australia: prepared for the 2009 senate inquiry into bushfires in Australia, Canberra, Australia. CSIRO, Canberra, Australia.

Davidson-Hunt, I., and F. Berkes. 2003. Learning as you journey: Anishinaabe perception of social-ecological environments and adaptive learning. Conservation Ecology 8(1):5. https://doi. org/10.5751/ES-00587-080105

Denevan, W. 1992. The pristine myth: the landscape of the Americas in 1492. Annals of the Association of American Geographers 82(3):369-385. https://doi.org/10.1111/j.1467-8306.1992. $\underline{\text { tb01965.x }}$

Denham, D. 2017. Community forest owners evaluate a decade of payments for ecosystem services in the Mexican Cloud Forest: the importance of attention to Indigenous sovereignty in conservation. Society \& Natural Resources 30(9):1064-1079. https://doi.org/10.1080/08941920.2017.1295495

Diver, S. 2016. Co-management as a catalyst: pathways to postcolonial forestry in the Klamath Basin, California. Human Ecology 44:533-546. https://doi.org/10.1007/s10745-016-9851-8

Eloy, L., B. A. Bilbao, J. Mistry, and I. B. Schmidt. 2018. From fire suppression to fire management: advances and resistances to changes in fire policy in the savannas of Brazil and Venezuela. Geographical Journal 185(1):10-22. https://doi.org/10.1111/ geoj.12245

Eriksen, C., and D. L. Hankins. 2014. The retention, revival, and subjugation of Indigenous fire knowledge through agency fire fighting in eastern Australia and California. Society \& Natural Resources 27(12):1288-1303. https://doi.org/10.1080/08941920.2$\underline{014.918226}$

Fache, E., and B. Moizo. 2015. Do burning practices contribute to caring for country? Contemporary uses of fire for conservation purposes in Indigenous Australia. Journal of Ethnobiology 35 (1):163-182. https://doi.org/10.2993/0278-0771-35.1.163

Fernandes, P. M., and H. S. Botelho. 2003. A review of prescribed burning effectiveness in fire hazard reduction. International
Journal of Wildland Fire 12:117-128. https://doi.org/10.1071/ WF02042

Fernández-Llamazares, Á., and M. Cabeza. 2018. Rediscovering the potential of Indigenous storytelling for conservation practice. Conservation Letters 11(3):e12398. https://doi.org/10.1111/ $\underline{\text { conl. } 12398}$

Fitzsimons, J., J. Russell-Smith, G. James, T. Vigilante, G. LipsettMoore, J. Morrison, and M. Looker. 2012. Insights into the biodiversity and social benchmarking components of the Northern Australian fire management and carbon abatement programmes. Ecological Management \& Restoration 13(1):51-57. https://doi.org/10.1111/j.1442-8903.2011.00624.x

Flannigan, M. D., M. A. Krawchuk, W. J. de Groot, B. M. Wotton, and L. M. Gowman. 2009. Implications of changing climate for global wildland fire. International Journal of Wildland Fire 18:483-507. https://doi.org/10.1071/WF08187

Forests and Rangelands. 2014. The national strategy: the final phase in the development of the National Cohesive Wildland Fire Management Strategy. Forests and Rangelands, U.S. Department of the Interior, Washington, D.C., USA. [online] URL: https:// www.forestsandrangelands.gov/strategy/thestrategy.shtml

Fulé, P. Z., M. Ramos-Gómez., C. Cortés-Montaño, and A. M. Miller. 2011. Fire regime in a Mexican forest under indigenous resource management. Ecological Applications 21(3):764-775. https://doi.org/10.1890/10-0523.1

Fuller, T. 2020. Reducing fire, and cutting carbon emissions, the Aboriginal way. New York Times, 16 January. [online] URL: https://www.nytimes.com/2020/01/16/world/australia/aboriginalfire-management.html

Gomes, G. L. 2018. Elements in the atomism theory, according to Aristotle. Hypnos 41:146-165.

Gowlett, J. A. J. 2016. The discovery of fire by humans: a long and convoluted process. Philosophical Transactions of the Royal Society B: Biological Sciences 371(1696). https://doi.org/10.1098/ rstb.2015.0164

Gratani, M., S. G. Sutton, J. R. A. Butler, E. L. Bohensky, and S. Foale. 2016. Indigenous environmental values as human values. Cogent Social Sciences 2(1):1185811. https://doi. org/10.1080/23311886.2016.1185811

Hankins, D. L. 2013. The effects of indigenous prescribed fire on riparian vegetation in central California. Ecological Processes 2:24. https://doi.org/10.1186/2192-1709-2-24

Hardesty, J., R. Myers, and W. Fulks. 2005. Fire, ecosystems and people: a preliminary assessment of fire as a global conservation issue. The Nature Conservancy, Global Fire Initiative, Arlington, Virginia, USA. [online] URL: http://www.georgewright. org/224hardesty.pdf

Harris, J. A., R. J. Hobbs, E. Higgs, and J. Aronson. 2006. Ecological restoration and global climate change. Restoration Ecology 14(2):170-176. https://doi.org/10.1111/j.1526-100X.2006.00136. $\underline{x}$

Henry, E., and H. Pene. 2001. Kaupapa Maori: locating Indigenous ontology, epistemology and methodology in the 
academy. Organization 8(2):234-242. https://doi.org/10.1177/13$\underline{50508401082009}$

Huffman, M. R. 2013. The many elements of traditional fire knowledge: synthesis, classification, and aids to cross-cultural problem solving in fire-dependent systems around the world. Ecology and Society 18(4):3. https://doi.org/10.5751/ES-05843-180403

Hunt, S. 2014. Ontologies of indigeneity: the politics of embodying a concept. Cultural Geographies 21(1):27-32. https:// doi.org/10.1177/1474474013500226

Ingalsbee, T. 2017. Whither the paradigm shift? Large wildland fires and the wildfire paradox offer opportunities for a new paradigm of ecological fire management. International Journal of Wildland Fire 26(7):557-561. https://doi.org/10.1071/WF17062

Jabareen, Y. 2009. Building a conceptual framework: philosophy, definitions, and procedure. International Journal of Qualitative Methods 8(4):49-62. https://doi.org/10.1177/160940690900800406

Jasanoff, S. 2004. What inquiring minds should want to know. Studies in History and Philosophy of Science Part A 35:149-157. https://doi.org/10.1016/j.shpsa.2003.12.004

Jolly, W. M., M. A. Cochrane, P. H. Freeborn, Z. A. Holden, T. J. Brown, G. J. Williamson, and D. M. J. S. Bowman. 2015. Climate-induced variations in global wildfire danger from 1979 to 2013. Nature Communications 6:7537. https://doi.org/10.1038/ ncomms 8537

Jones, R. 2012. Fire-stick farming. Fire Ecology 8:3-8. https://doi. org/10.1007/BF03400623

Judson, K. B. 1912. Myths and legends of the Pacific Northwest. Jazzybee Verlag Jürgen Beck, Altenmünster, Germany.

Kelly, L. T., D. G. Nimmo, L. M. Spence-Bailey, R. S. Taylor, S. J. Watson, M. F. Clarke, and A. F. Bennett. 2012. Managing fire mosaics for small mammal conservation: a landscape perspective. Journal of Applied Ecology 49(2):412-421. https://doi. org/10.1111/j.1365-2664.2012.02124.X

Kidwell, C. S., H. Noley, and G. E. Tinker. 2002. A Native American theology. Orbis Books, Maryknoll, New York, USA.

Kimmerer, R. W., and F. K. Lake. 2001. Maintaining the mosaic - the role of indigenous burning in land management. Journal of Forestry 99(11):36-41.

Klimaszewski-Patterson, A., P. J. Weisberg, S. A. Mensing, and R. M. Scheller. 2018. Using paleolandscape modeling to investigate the impact of Native American-set fires on PreColumbian forests in the Southern Sierra Nevada, California, USA. Annals of the American Association of Geographers 108 (6):1635-1654. https://doi.org/10.1080/24694452.2018.1470922

Kondratiev, V. N. 2018. Combustion. In Encyclopadia Britannica. Encyclopædia Britannica, Chicago, Illinois, USA. [online] URL: https://www.britannica.com/science/combustion

Krawchuk, M. A., M. A. Moritz, M.-A. Parisien, J. Van Dorn, and K. Hayhoe. 2009. Global pyrogeography: the current and future distribution of wildfire. PLOS ONE4(4):e5102. https://doi. org/10.1371/journal.pone.0005102

Kull, C. A. 2002. Madagascar aflame: landscape burning as peasant protest, resistance, or a resource management tool?
Political Geography 21(7):927-953. https://doi.org/10.1016/ $\underline{\text { S0962-6298(02)00054-9 }}$

Lake, F. K., and A. C. Christianson. 2019. Indigenous fire stewardship. Pages 1-9 in S. Mazello, editor. Encyclopedia of wildfire and wildland-urban interface (WUI) fires. Springer, Cham, Switzerland. https://doi.org/10.1007/978-3-319-51727-8 225-1

Lake, F. K., V. Wright, P. Morgan, M. McFadzen, D. McWethy, and C. Stevens-Rumann. 2017. Returning fire to the land: celebrating traditional knowledge and fire. Journal of Forestry 115 (5):343-353. https://doi.org/10.5849/jof.2016-043R2

Laris, P. 2002. Burning the seasonal mosaic: preventative burning strategies in the wooded savanna of southern Mali. Human Ecology 30(2):155-186.

Latta, A. 2018. Indigenous rights and multilevel governance: learning from the Northwest Territories water stewardship strategy. International Indigenous Policy Journal 9(2). https://doi. org/10.18584/iipj.2018.9.2.4

Lepofsky, D., and K. Lertzman. 2008. Documenting ancient plant management in the northwest of North America. Botany 86:129-145. https://doi.org/10.1139/B07-094

Lewis, M., A. Christianson, and M. Spinks. 2018. Return to flame: reasons for burning in Lytton First Nation, British Columbia. Journal of Forestry 116(2):143-150. https://doi.org/10.1093/ jofore/fvx007

Maffi, L., and E. Woodley. 2010. Biocultural diversity conservation: a global sourcebook. Earthscan, London, UK. https://doi.org/10.4324/9781849774697

Maguire, L. A., and E. A. Albright. 2005. Can behavioral decision theory explain risk-averse fire management decisions? Forest Ecology and Management 211(1-2):47-58. https://doi.org/10.1016/ j.foreco.2005.01.027

Marsden-Smedley, J. B., and J. B. Kirkpatrick. 2000. Fire management in Tasmania's wilderness world heritage area: ecosystem restoration using Indigenous-style fire regimes? Ecological Management \& Restoration 1(3):195-203. https://doi. org/10.1046/j.1442-8903.2000.00052.x

Martin, R. E., and D. B. Sapsis. 1992. Fires as agents of biodiversity: pyrodiversity promotes biodiversity. Pages 150-157 in H. M. Kerner, editor. Proceedings of the Symposium on Biodiversity in Northwestern California. Wildland Resources Centre, University of California, Berkeley, California, USA.

Mason, L., G. White, G. Morishima, E. Alvarado, L. Andrew, F. Clark, M. Durglo, J. Durglo, J. Eneas, J. Erickson, et al. 2012. Listening and learning from traditional knowledge and Western science: a dialogue on contemporary challenges of forest health and wildfire. Journal of Forestry 110(4):187-193. https://doi. org/10.5849/jof.11-006

Mathews, A. S. 2005. Power/knowledge, power/ignorance: forest fires and the state in Mexico. Human Ecology 33(6):795-820. https://doi.org/10.1007/s10745-005-8211-x

McGregor, S., V. Lawson, P. Christophersen, R. Kennett, J. Boyden, P. Bayliss, A. Liedloff, B. McKaige, and A. N. Andersen. 2010. Indigenous wetland burning: conserving natural and cultural resources in Australia's world heritage-listed Kakadu 
National Park. Human Ecology 38:721-729. https://doi. org/10.1007/s10745-010-9362-y

Miller, A. M., and I. Davidson-Hunt. 2010. Fire, agency and scale in the creation of aboriginal cultural landscapes. Human Ecology 38:401-414. https://doi.org/10.1007/s10745-010-9325-3

Miller, A. M., I. Davidson-Hunt, and P. Peters. 2010. Talking about fire: Pikangikum First Nation elders guiding fire management. Canadian Journal of Forest Research 40:2290-2301. https://doi.org/10.1139/X10-177

Minor, J., and G. A. Boyce. 2018. Smokey Bear and the pyropolitics of United States forest governance. Political Geography 62:79-93. https://doi.org/10.1016/j.polgeo.2017.10.005

Mistry, J., and A. Berardi. 2016. Bridging indigenous and scientific knowledge. Science 352(6291):1274-1275. https://doi. org/10.1126/science.aaf1160

Mistry, J., B. A. Bilbao, and A. Berardi. 2016. Community owned solutions for fire management in tropical ecosystems: case studies from Indigenous communities of South America. Philosophical Transactions of the Royal Society B: Biological Sciences 371 (1696). https://doi.org/10.1098/rstb.2015.0174

Mistry, J., I. B. Schmidt, L. Eloy, and B. Bilbao. 2019. New perspectives in fire management in South American savannas: the importance of intercultural governance. Ambio 48:172-179. https://doi.org/10.1007/s13280-018-1054-7

Moller, H., P. O'Blyver, C. Bragg, J. Newman, R. Clucas, D. Fletcher, J. Kitson, S. McKechnie, D. Scott, and Rakiura Titi Islands Administering Body. 2009. Guidelines for cross-cultural participatory action research partnerships: a case study of a customary seabird harvest in New Zealand. New Zealand Journal of Zoology 36(3):211-241. https://doi.org/10.1080/03014220909510152

Moritz, M. A., M.-A. Parisien, E. Batllori, M. A. Krawchuk, J. Van Dorn, D. J. Ganz, and K. Hayhoe. 2012. Climate change and disruptions to global fire activity. Ecosphere 3(6):1-22. https://doi. org/10.1890/ES11-00345.1

Moura, L. C., A. O. Scariot, I. B. Schmidt, R. Beatty, and J. Russell-Smith. 2019. The legacy of colonial fire management policies on traditional livelihoods and ecological sustainability in savannas: impacts, consequences, new directions. Journal of Environmental Management 232:600-606. https://doi.org/10.1016/ j.jenvman.2018.11.057

Nikolakis, W. 2019. The evolution of Indigenous self-governance in Canada. Pages 55-70 in W. Nikolakis, S. Cornell, and H. Nelson, editors. Reclaiming Indigenous governance: reflections and insights from Australia, Canada, New Zealand, and the United States. University of Arizona Press, Tucson, Arizona, USA. https://doi. org/10.2307/j.ctvqc6jwv.7

Nikolakis, W. 2020. Participatory backcasting: building pathways towards reconciliation? Futures 122:102603. https://doi. org/10.1016/j.futures.2020.102603

Nikolakis, W., S. Akter, and H. W. Nelson. 2016a. The effect of communication on individual preferences for common property resources: a case study from two Canadian First Nations. Land Use Policy 58:70-82. https://doi.org/10.1016/j.landusepol.2016.07.007
Nikolakis, W., Q. Grafton, and A. Nygaard. 2016b. Indigenous communities and climate change: a recognition, empowerment and devolution (RED) framework in the Murray-Darling Basin, Australia. Journal of Water and Climate Change 7(1):169-183. https://doi.org/10.2166/wcc.2015.058

Nikolakis, W., and N. Hotte. 2020. How law shapes collaborative forest governance: a focus on Indigenous peoples in Canada and India. Society \& Natural Resources 33(1):46-64. https://doi. org/10.1080/08941920.2019.1605433

Nikolakis, W., and H. Nelson. 2015. To log or not to log? How forestry fits with the goals of First Nations in British Columbia. Canadian Journal of Forest Research 45(6):639-646. https://doi. org/10.1139/cjfr-2014-0349

Nikolakis, W., and H. Nelson. 2019. Trust, institutions, and indigenous self-governance: an exploratory study. Governance 32 (2):331-347. https://doi.org/10.1111/gove.12374

Nikolakis, W., E. Roberts, N. Hotte, and R. Myers-Ross. 2020. Goal setting and Indigenous fire management: a holistic perspective. International Journal of Wildland Fire. https://doi. org/10.1071/WF20007

Nimmo, D. G., L. T. Kelly, L. M. Spence-Bailey, S. J. Watson, R. S. Taylor, M. F. Clarke, and A. F. Bennett. 2013. Fire mosaics and reptile conservation in a fire-prone region. Conservation Biology 27(2):345-353. https://doi.org/10.1111/j.1523-1739.2012.01958.x

Norgaard, K. M. 2014. The politics of fire and the social impacts of fire exclusion on the Klamath. Humboldt Journal of Social Relations 36:77-101.

North, M. P., S. L. Stephens, B. M. Collins, J. K. Agee, G. Aplet, J. F. Franklin, and P. Z. Fulé. 2015. Reform forest fire management. Science 349(6254):1280-1281. https://doi.org/10.1126/ $\underline{\text { science.aab2356 }}$

Northern Australia Environmental Resources Hub. 2016. Report on the National Indigenous Fire Knowledge and Fire Management Forum. CSIRO, Canberra, Australia. [online] URL: https://www. nespnorthern.edu.au/wp-content/uploads/2016/05/National-IndigenousFire-Knowledge-Forum-Report-2016_FINAL.pdf

Papworth, S. K., J. Rist, L. Coad, and E. J. Milner-Gulland. 2009. Evidence for shifting baseline syndrome in conservation. Conservation Letters 2:93-100. https://doi.org/10.1111/ j.1755-263x.2009.00049.x

Parr, C. L., and A. N. Andersen. 2006. Patch mosaic burning for biodiversity conservation: a critique of the pyrodiversity paradigm. Conservation Biology 20(6):1610-1619. https://doi. org/10.1111/j.1523-1739.2006.00492.x

Partington, J. R., and D. McKie. 1937. Historical studies on the phlogiston theory.-I. The levity of phlogiston. Annals of Science 2(4):361-404. https://doi.org/10.1080/00033793700200691

Pellatt, M. G., and Z. Gedalof. 2014. Environmental change in Garry oak (Quercus garryana) ecosystems: the evolution of an eco-cultural landscape. Biodiversity and Conservation 23 (8):2053-2067. https://doi.org/10.1007/s10531-014-0703-9

Petty, A. M., V. deKoninck, and B. Orlove. 2015. Cleaning, protecting, or abating? Making Indigenous fire management 
"work" in Northern Australia. Journal of Ethnobiology 35 (1):140-162. https://doi.org/10.2993/0278-0771-35.1.140

Pierotti, R. 2018. World views and the concept of "traditional." Ethnobiology Letters 9(2):299-304. https://doi.org/10.14237/ eb1.9.2.2018.1394

Pivello, V. R. 2011. The use of fire in the Cerrado and Amazonian Rainforests of Brazil: past and present. Fire Ecology 7:24-39. https://doi.org/10.4996/fireecology.0701024

Potter, J. 1996. Representing reality: discourse, rhetoric and social construction. Sage, London, UK. https://doi.org/10.4135/9781446222119

Pyne, S. J. 1982. Fire in America: a cultural history of wildland and rural fire. Princeton University Press, Princeton, New Jersey, USA.

Pyne, S. J. 2016. Fire in the mind: changing understandings of fire in Western civilization. Philosophical Transactions of the Royal Society B: Biological Sciences 371(1696). https://doi. org/10.1098/rstb.2015.0166

Rasmussen, K., M. Hibbard, and K. Lynn. 2007. Wildland fire management as conservation-based development: an opportunity for reservation communities? Society \& Natural Resources 20 (6):497-510. https://doi.org/10.1080/08941920701337952

Ritchie, D. 2009. Things fall apart: the end of an era of systematic indigenous fire management. Pages 23-40 in J. Russell-Smith, P. J. Whitehead, P. M. Cooke, editors. Culture, ecology and economy of fire management in northern Australian savannas: rekindling the Wurrk tradition. CSIRO, Melbourne, Australia. https://doi. org/10.1071/9780643098299

Robinson, C. J., G. James, and P. J. Whitehead. 2016. Negotiating Indigenous benefits from payment for ecosystem service (PES) schemes. Global Environmental Change 38:21-29. https://doi. org/10.1016/j.gloenvcha.2016.02.004

Rodríguez, I. 2007. Pemon perspectives of fire management in Canaima National Park, southeastern Venezuela. Human Ecology 35:331-343. https://doi.org/10.1007/s10745-006-9064-7

Rodriguez, I. 2017. Linking well-being with cultural revitalization for greater cognitive justice in conservation: lessons from Venezuela in Canaima National Park. Ecology and Society 22 (4):24. https://doi.org/10.5751/ES-09758-220424

Russell-Smith, J., G. Cook, P. Cooke, A. Edwards, M. Lendrum, C. Meyer, and P. Whitehead. 2013. Managing fire regimes in north Australian savannas: applying Aboriginal approaches to contemporary global problems. Frontiers in Ecology and the Environment 11:e55-e63. https://doi.org/10.1890/120251

Russell-Smith, J., C. Monagle, M. Jacobsohn, R. L. Beatty, B. Bilbao, A. Millán, H. Vessuri, and I. Sánchez-Rose. 2017. Can savanna burning projects deliver measurable greenhouse emissions reductions and sustainable livelihood opportunities in fire-prone settings? Climatic Change 140:47-61. https://doi. org/10.1007/s10584-013-0910-5

Russell-Smith, J., C. P. Yates, A. C. Edwards, P. J. Whitehead, B. P. Murphy, and M. J. Lawes. 2015. Deriving multiple benefits from carbon market-based savanna fire management: an Australian example. PLoS ONE 10(12):e0143426. https://doi.org/10.1371/ journal.pone. 0143426
Ryan, K. C., E. E. Knapp, and J. M. Varner. 2013. Prescribed fire in North American forests and woodlands: history, current practice, and challenges. Frontiers in Ecology and the Environment 11(1):e15-e24. https://doi.org/10.1890/120329

Saveland, J. 1998. Prescribed fire: the fundamental solution. Pages 12-16 in T. L. Pruden and L. A. Brennan, editors. Fire in ecosystem management: shifting the paradigm from suppression to prescription. Tall Timbers Fire Ecology Conference Proceedings, No. 20. Tallahassee, Florida, USA.

Shaffer, L. J. 2010. Indigenous fire use to manage savanna landscapes in southern Mozambique. Fire Ecology 6:43-59. https://doi.org/10.4996/fireecology.0602043

Singh, K. D. 2015. Creating your own qualitative research approach: selecting, integrating and operationalizing philosophy, methodology and methods. Vision 19(2):132-146. https://doi. org/10.1177/0972262915575657

Sletto, B. 2016. Indigenous mobilities, territorialization, and dispossession in the Sierra de Perijá, Venezuela: rescuing lands and meanings in Hábitat Indígena Yukpa, Toromo-Tütari. Geoforum 74:117-127. https://doi.org/10.1016/j.geoforum.2016.06.003

Sletto, B., and I. Rodríguez. 2013. Burning, fire prevention and landscape productions among the Pemon, Gran Sabana, Venezuela: toward an intercultural approach to wildland fire management in Neotropical Savannas. Journal of Environmental Management 115:155-166. https://doi.org/10.1016/j.jenvman.2012.10.041

Stankey, G. H., B. T. Bormann, C. Ryan, B. Shindler, V. Sturtevant, R. N. Clark, and C. Philpot. 2003. Adaptive management and the Northwest Forest Plan: rhetoric and reality. Journal of Forestry Research 101(1):40-46.

Steen-Adams, M. M., S. Charnley, R. J. McLain, M. D. O. Adams, and K. L. Wendel. 2019. Traditional knowledge of fire use by the Confederated Tribes of Warm Springs in the eastside Cascades of Oregon. Forest Ecology and Management 450:117405. https:// doi.org/10.1016/j.foreco.2019.06.002

Taylor, R. S., S. J. Watson, D. G. Nimmo, L. T. Kelly, A. F. Bennett, and M. F. Clarke. 2012. Landscape-scale effects of fire on bird assemblages: does pyrodiversity beget biodiversity? Diversity and Distributions 18(5):519-529. https://doi.org/10.1111/ j.1472-4642.2011.00842.X

Trauernicht, C., B. W. Brook, B. P. Murphy, G. J. Williamson, and D. M. J. S. Bowman. 2015. Local and global pyrogeographic evidence that indigenous fire management creates pyrodiversity. Ecology and Evolution 5(9):1908-1918. https://doi.org/10.1002/ ece3.1494

United Nations Office for Disaster Risk Reduction. 2015. Sendai Framework for Disaster Risk Reduction 2015 - 2030. United Nations Office for Disaster Risk Reduction, Geneva, Switzerland. [online] URL: https://www.unisdr.org/files/43291 sendaiframeworkfordrren.pdf

Walker, B., and D. Salt. 2006. Resilience thinking: sustaining ecosystems and people in a changing world. Island Press, Washington, D.C., USA.

Welch, J. R., and C. E. A. Coimbra. 2019. Indigenous fire ecologies, restoration, and territorial sovereignty in the Brazilian 
Cerrado: the case of two Xavante reserves. Land Use Policy 104055. https://doi.org/10.1016/j.landusepol.2019.104055

Wheelwright, P. 1974. Heraclitus. Colchis Books, Istanbul, Turkey.

Whitehair, L., P. Z. Fulé, A. S. Meador, A. A. Tarancón, and Y. Kim. 2018. Fire regime on a cultural landscape: Navajo Nation. Ecology and Evolution 8:9848-9858. https://doi.org/10.1002/ ece3.4470

Whitehead, P. J., P. Purdon, J. Russell-Smith, P. M. Cooke, and S. Sutton. 2008. The management of climate change through prescribed Savanna burning: emerging contributions of indigenous people in Northern Australia. Public Administration and Development 28(5):374-385. https://doi.org/10.1002/pad.512

Wiebe, R. 2008. The metaphysics of fire hating: demonic creatures and devil winds. Pacific Journal 3:111-133.

Wrangham, R. 2009. Catching fire: hw cooking made us human. Profile Books, London, UK.

Yibarbuk, D., P. J. Whitehead, J. Russell-Smith, D. Jackson, C. Godjuwa, A. Fisher, P. Cooke, D. Choquenot, and D. M. J. S. Bowman. 2001. Fire ecology and Aboriginal land management in Central Arnhem Land, northern Australia: a tradition of ecosystem management. Journal of Biogeography 28(3):325-343. https://doi.org/10.1046/j.1365-2699.2001.00555.x

Zander, K. K., D. R. Dunnett, C. Brown, O. Campion, and S. T. Garnett. 2013. Rewards for providing environmental services Where indigenous Australians' and western perspectives collide. Ecological Economics 87:145-154. https://doi.org/10.1016/j. ecolecon.2012.12.029 
Appendix 1. Data for bibliometric analysis.

Publications included in the Literature Review $(N=72)$.

Anderson, M. K., J. Rosenthal. 2015. An Ethnobiological Approach to Reconstructing Indigenous Fire Regimes in the Foothill Chaparral of the Western Sierra Nevada. Journal of Ethnobiology 35(1):4-36.

Bilbao, B. A., A. V. Leal, and C. L. Méndez. 2010. Indigenous Use of Fire and Forest Loss in Canaima National Park, Venezuela. Assessment of and Tools for Alternative Strategies of Fire Management in Pemón Indigenous Lands. Human Ecology 38(5):663-673.

Bird, D. W., R. B. Bird, B. F. Codding, and N. Taylor. 2016. A Landscape Architecture of Fire: Cultural Emergence and Ecological Pyrodiversity in Australia's Western Desert. Current Anthropology 57(13):S65-S79.

Bird, R. B., D. W. Bird, L. E. Fernandez, N. Taylor, and D. Nimmo. 2018. Aboriginal burning promotes fine-scale pyrodiversity and native predators in Australia's Western Desert. Biological Conservation 219:110-118.

Bowman, D. M. J. S., A. Walsh, and L. D. Prior. 2004. Landscape analysis of Aboriginal fire management in Central Arnhem Land, north Australia. Journal of Biogeography 31:207-223.

Bowman, D. M. J. S., J. Balch, P. Artaxo, W. J. Bond, M. A. Cochrane, C. M. D’Antonio, ... T. W. Swetnam. 2011. The human dimension of fire regimes on Earth. Journal of Biogeography 38(12):2223-2236.

Bowman, D. M. J. S., G. L. W. Perry, S. I. Higgins, C. N. Johnson, S. D. Fuhlendorf, and B. P. Murphy. 2016. Pyrodiversity is the coupling of biodiversity and fire regimes in food webs. Philosophical Transactions of the Royal Society B: Biological Sciences 371.

Buizer, M. and T. Kurz. 2016. Too hot to handle: Depoliticisation and the discourse of ecological modernisation in fire management debates. Geoforum 68:48-56.

Burgess, C. P., F. H. Johnston, D. M. J. S. Bowman, and P. J. Whitehead. 2005. Healthy Country: Healthy People? Exploring the health benefits of Indigenous natural resource management. Australian and New Zealand Journal of Public Health 29(2):117-122.

Butz, R. J. 2009. Traditional fire management: historical fire regimes and land use change in pastoral East Africa. International Journal of Wildland Fire 18(4):442-450. 
Campbell, D., C. Burgess, S. Garnett, and J. Wakerman. 2011. Potential primary health care savings for chronic disease care associated with Australian Aboriginal involvement in land management. Health Policy 99(1):83-89.

Carroll, M., P. Cohen, and K. Blatner. 2004. Private and Tribal Forest Landowners and Fire Risk: a Two County Case Study in Washington State. Canadian Journal of Forest Research, 34:21482158.

Charnley, S., M. R. Poe, A. A. Ager, T. A. Spies, E. K. Platt, and K. A. Olsen. 2015. A Burning Problem: Social Dynamics of Disaster Risk Reduction through Wildfire Mitigation. Human Organization 74(4):329-340.

Christianson, A. 2015. Social science research on Indigenous wildfire management in the 21st century and future research needs. International Journal of Wildland Fire 24:190200.

Christianson, A., T. K. McGee, and L. L'Hirondelle. 2014. The Influence of Culture on Wildfire Mitigation at Peavine Métis Settlement, Alberta, Canada. Society \& Natural Resources 27:931947.

Codding, B.F., R. B. Bird, P. G. Kauhanen, and D. W. Bird. 2014. Conservation or Co-evolution? Intermediate Levels of Aboriginal Burning and Hunting Have Positive Effects on Kangaroo Populations in Western Australia. Human Ecology 42:659-669.

Eloy, L., B. Bilbao, J. Mistry, and I. Schmidt. 2018. From fire suppression to fire management: Advances and resistances to changes in fire policy in the savannas of Brazil and Venezuela. The Geographical Journal.

Eriksen, C. and D. L. Hankins. 2014. The Retention, Revival, and Subjugation of Indigenous Fire Knowledge through Agency Fire Fighting in Eastern Australia and California. Society \& Natural Resources 27(12):1288-1303.

Fache, E. and B. Moizo. 2015. Do Burning Practices Contribute to Caring for Country? Contemporary Uses of Fire for Conservation Purposes in Indigenous Australia. Journal of Ethnobiology 35(1):163-182.

Fitzsimons, J., J. Russell-Smith, G. James, T. Vigilante, G. Lipsett-Moore, J. Morrison, and M. Looker. 2012. Insights into the biodiversity and social benchmarking components of the Northern Australian fire management and carbon abatement programmes. Ecological Management \& Restoration 13(1):51-57.

Fulé, P. Z., M. Ramos-Gómez., C. Cortés-Montaño, and A. M. Miller. 2011. Fire regime in a Mexican forest under indigenous resource management. Ecological Applications 21(3):764-775. 
Gott, B. 2005. Aboriginal Fire Management in South-Eastern Australia: Aims and Frequency. Journal of Biogeography 32(7):1203-1208.

Hankins, D. L. 2013. The effects of indigenous prescribed fire on riparian vegetation in central California. Ecological Processes 2(24).

Heckbert, S., J. Russell-Smith, A. Reeson, and G. James. 2011. Indigenous Australians Fight Climate Change with Fire. Solutions Journal 2(6):50-56.

Huffman, M. R. 2013. The Many Elements of Traditional Fire Knowledge: Synthesis, Classification, and Aids to Cross-cultural Problem Solving in Fire-dependent Systems Around the World. Ecology and Society 18(4):3.

Jones, R. 2012. Fire-stick farming. Fire Ecology 8(3):3-8.

Kelly, L. T., D. G. Nimmo, L. M. Spence-Bailey, R. S. Taylor, S. J. Watson, M. F. Clarke, and A. F. Bennett. 2012. Managing fire mosaics for small mammal conservation: a landscape perspective. Journal of Applied Ecology 49(2):412-421.

Kimmerer, R. W. \& F. K. Lake. 2001. Maintaining the mosaic - The role of indigenous burning in land management. Journal of Forestry 99(11):36-41.

Klimaszewski-Patterson, A., P. J. Weisberg, S. A. Mensing, and R. M. Scheller. 2018. Using Paleolandscape Modeling to Investigate the Impact of Native American-Set Fires on PreColumbian Forests in the Southern Sierra Nevada, California, USA. Annals of the American Association of Geographers 108(6):1635-1654.

Kull, C. A. 2002. Madagascar aflame: landscape burning as peasant protest, resistance, or a resource management tool? Political Geography 21(7):927-953.

Lake, F. K., V. Wright, P. Morgan, M. McFadzen, D. McWethy, and C. Stevens-Rumann. 2017. Returning Fire to the Land: Celebrating Traditional Knowledge and Fire. Journal of Forestry 115(5):343-353.

Laris, P. 2002. Burning the Seasonal Mosaic: Preventative Burning Strategies in the Wooded Savanna of Southern Mali. Human Ecology 30(2):155-186.

Lewis, M., A. Christianson, and M. Spinks. 2018. Return to Flame: Reasons for Burning in Lytton First Nation, British Columbia. Journal of Forestry 116(2):143-150.

Marsden-Smedley, J. B. and J. B. Kirkpatrick. 2000. Fire management in Tasmania's Wilderness World Heritage Area: Ecosystem restoration using Indigenous-style fire regimes? Ecological Management \& Restoration 1(3):195-203. 
Mason, L., G. White, G. Morishima, E. Alvarado, L. Andrew, F. Clark, ... S. Wilder. 2012. Listening and Learning from Traditional Knowledge and Western Science: A Dialogue on Contemporary Challenges of Forest Health and Wildfire. Journal of Forestry 110(4):187-193.

Mathews, A. S. 2005. Power/Knowledge, Power/Ignorance: Forest Fires and the State in Mexico. Human Ecology 33(6):795-820

McDaniel, J., D. Kennard, and A. Fuentes. 2005. Smokey the tapir: traditional fire knowledge and fire prevention campaigns in lowland Bolivia. Society and Natural Resources 18(10):921931.

McGregor, S., V. Lawson, P. Christophersen, R. Kennett, J. Boyden, P. Bayliss, ... A. N. Andersen. 2010. Indigenous Wetland Burning: Conserving Natural and Cultural Resources in Australia's World Heritage-listed Kakadu National Park. Human Ecology 38:721-729.

Miller, A. M., and I. Davidson-Hunt. 2010. Fire, agency and scale in the creation of aboriginal cultural landscapes. Human Ecology 38(3):401-414.

Miller, A. M., I. Davidson-Hunt, and P. Peters. 2010. Talking about fire: Pikangikum First Nation elders guiding fire management. Canadian Journal of Forest Research 40:2290-2301.

Mistry, J., A. Berardi, V. Andrade, T. Krahô, P. Krahô, and O. Leonardos. 2005. Indigenous Fire Management in the cerrado of Brazil: The Case of the Krahô of Tocantíns. Human Ecology 33(3):365-386.

Mistry, J., B. A. Bilbao, and A. Berardi. 2016. Community owned solutions for fire management in tropical ecosystems: case studies from Indigenous communities of South America. Philosophical Transactions of the Royal Society B: Biological Sciences 371:1-10.

Mistry, J., I. B. Schmidt, L. Eloy, and B. Bilbao. 2019. New perspectives in fire management in South American savannas: The importance of intercultural governance. Ambio 48(2):172-179.

Moura, L. C., Scariot, A. O., Schmidt, I. B., Beatty, R., \& Russell-Smith, J. (2019). The legacy of colonial fire management policies on traditional livelihoods and ecological sustainability in savannas: Impacts, consequences, new directions. Journal of Environmental Management, 232: 600-606.

Norgaard, K. M. 2014. The Politics of Fire and the Social Impacts of Fire Exclusion on the Klamath. Humboldt Journal of Social Relations 36:77-101.

Pellatt, M. G. and Z. Gedalof. 2014. Environmental change in Garry oak (Quercus garryana) ecosystems: the evolution of an eco-cultural landscape. Biodiversity and Conservation 23(8):2053-2067. 
Perry, J. J., M. Sinclair, H. Wikmunea, S. Wolmby, \& D. Martin. 2018. The divergence of traditional Aboriginal and contemporary fire management practices on Wik traditional lands, Cape York Peninsula, Northern Australia. Ecological Management \& Restoration 19(1):24-31.

Petty, A. M., V. deKoninck, and B. Orlove. 2015. Cleaning, Protecting, or Abating? Making Indigenous Fire Management "Work" in Northern Australia. Journal of Ethnobiology 35(1):140162.

Pivello, V. R. 2011. The Use of Fire in the Cerrado and Amazonian Rainforests of Brazil: Past and Present. Fire Ecology 7(1):24-39.

Prober, S. M., E. Yuen, M. H. O'Connor, and L. Schultz. 2016. Ngadju kala: Australian Aboriginal fire knowledge in the Great Western Woodlands. Austral Ecology 41:716- 732.

Raish, C., A. González-Cabán, and C. J. Condie. 2005. The importance of traditional fire use and management practices for contemporary land managers in the American Southwest. Global Environmental Change Part B: Environmental Hazards 6(2):115-122

Rasmussen, K., M. Hibbard, and K. Lynn. 2007. Wildland Fire Management as ConservationBased Development: An Opportunity for Reservation Communities? Society \& Natural Resources 20(6):497-510.

Richards, A. E., A. N. Andersen, J. Schatz, R. Eager, T. Z. Dawes, K. Hadden, K. Scheepers, and M. van der Geest. 2012. Savanna burning, greenhouse gas emissions and indigenous livelihoods: Introducing the Tiwi Carbon Study. Austral Ecology 37(6):712-723.

Robinson, C. J., G. James, and P. J. Whitehead. 2016. Negotiating Indigenous benefits from payment for ecosystem service (PES) schemes. Global Environmental Change 38:21-29.

Rodríguez, I. 2007. Pemon Perspectives of Fire Management in Canaima National Park, Southeastern Venezuela. Human Ecology 35(3):331-343.

Rodríguez, I. 2017. Linking well-being with cultural revitalization for greater cognitive justice in conservation: lessons from Venezuela in Canaima National Park. Ecology and Society 22(4):24.

Roos, C. I., A. C. Scott, C. M. Belcher, W. G. Chaloner, J. Aylen, R. B. Bird, ... T. Steelman. Fire and Mankind Discussion Group (2016). Living on a flammable planet: interdisciplinary, crossscalar and varied cultural lessons, prospects and challenges. Philosophical Transactions of the Royal Society B: Biological Sciences 371(1696):20150469.

Russell-Smith, J., G. Cook, P. Cooke, A. Edwards, M. Lendrum, C. Meyer, and P. Whitehead. 2013. Managing fire regimes in north Australian savannas: applying Aboriginal approaches to contemporary global problems. Frontiers in Ecology and the Environment 11:e55-e63. 
Russell-Smith, J., C. P. Yates, A. C. Edwards, P. J. Whitehead, B. P. Murphy, and M. J. Lawes. 2015. Deriving Multiple Benefits from Carbon Market-Based Savanna Fire Management: An Australian Example. PLOS ONE 10(12):1-21.

Russell-Smith, J., C. Monagle, M. Jacobsohn, R. L. Beatty, B. Bilbao, A. Millán, ... I. Sánchez-Rose. 2017. Can savanna burning projects deliver measurable greenhouse emissions reductions and sustainable livelihood opportunities in fire-prone settings? Climatic Change 140(1):47-61.

Ryan, K. C., E. E. Knapp, and J. M. Varner. 2013. Prescribed fire in North American forests and woodlands: history, current practice, and challenges. Frontiers in Ecology and the Environment 11(1):e15-e24.

Shaffer, L. J. 2010. Indigenous Fire Use to Manage Savanna Landscapes in Southern Mozambique. Fire Ecology 6(2):43-59.

Sletto, B. and I. Rodríguez. 2013. Burning, fire prevention and landscape productions among the Pemon, Gran Sabana, Venezuela: Toward an intercultural approach to wildland fire management in Neotropical Savannas. Journal of Environmental Management 115:155-166.

Sletto, B. 2016. Indigenous mobilities, territorialization, and dispossession in the Sierra de Perijá, Venezuela: Rescuing lands and meanings in Hábitat Indígena Yukpa, ToromoTütari. Geoforum 74: 117-127.

Spoon, J, R. Arnold, B. J. Lefler, and C. Milton. 2015. Nuwuvi (Southern Paiute), Shifting Fire Regimes, and the Carpenter One Fire in the Spring Mountains National Recreation Area, Nevada. Journal of Ethnobiology 35(1):85-110.

Trauernicht, C., B. W. Brook, B. P, Murphy, G. J. Williamson, and D. M. J. S. Bowman. 2015. Local and global pyrogeographic evidence that indigenous fire management creates pyrodiversity. Ecology and Evolution 5(9):1908-1918.

Welch, J. R. and C. E. A. Coimbra. 2019. Indigenous fire ecologies, restoration, and territorial sovereignty in the Brazilian Cerrado: The case of two Xavante reserves. Land Use Policy 104055.

Whitehair, L., P. Z. Fule, A. S. Meador, A. A. Tarancon, and Y. Kim. 2018. Fire regime on a cultural landscape: Navajo Nation. Ecology and Evolution 8:9848-9858.

Whitehead, P. J., D. M. J. S. Bowman, N. Preece, F. Fraser, and P. Cooke. 2003. Customary use of fire by indigenous peoples in northern Australia: its contemporary role in savanna management. International Journal of Wildland Fire 12(4):415-425.

Whitehead, P. J., P. Purdon, J. Russell-Smith, P. M. Cooke, and S. Sutton. 2008. The management of climate change through prescribed Savanna burning: Emerging contributions of 
indigenous people in Northern Australia. Public Administration and Development 28(5):374wi385.

Wilman, E. A. 2015. An economic model of aboriginal fire-stick farming. The Australian Journal of Agricultural and Resource Economics 59:39-60.

Yibarbuk, D., P. J. Whitehead, J. Russell-Smith, D. Jackson, C. Godjuwa, A. Fisher, ... and D. M. J. S. Bowman. 2001. Fire Ecology and Aboriginal Land Management in Central Arnhem Land, Northern Australia: A Tradition of Ecosystem Management. Journal of Biogeography 28(3):325343. 